\title{
Religious Rationales for Homeschooling
}

Though, the appointment of Secretary of Education Betsy DeVos brought with it an overt agenda to not only dismantle public education as much as possible in favor of private schools, charter schools, and homeschooling but, to the extent that public schools could not be eradicated, DeVos and similar thinkers are determined to bring their particular religiosity into public schools. Case in point, DeVos stated that she wanted to use public schools to "build God's kingdom" (Rizga, 2017; Wermund, 2016). While DeVos represents some of these efforts at the federal level, state-level politicians have sought to bring religion and White supremacy into public schools. Cynthia Dunbar, a homeschooling parent and former member of the Texas School Board, is a good example of these efforts at the state level. Dunbar was among the leading champions for pushing to reshape Texas curriculum and textbooks (which are largely catered to Texas curriculum) into a narrow White Christian disposition hoping that changes in the science and social studies curriculum would more closely align with her belief that the United States was specifically designed to follow the Bible along a White-Protestant theocracy as explicated in her self-published book: "One Nation Under God: How the Left is Trying to Erase What Made us Great" (Dunbar, 2008). To the end that she believes the "left" is undermining the United States, during her time as a member of the Board, Dunbar penned an Op-Ed arguing that then President Barack Obama was secretly working with Islamic terrorists to help them plan and execute a terrorist attack in the United States in an effort to dismantle America (Associated Press, 2008).

Of course, Dunbar is not the only example of how these types of efforts continue to be promoted in state legislators as conservatives push for laws allowing for the overt teaching and support of Bible-based classes (Ryan, 2019; Sheasley \& Jonsson, 2019), official prayer in school, and even efforts to shield students from losing points on assignments if their answers are justified by their religious beliefs rather than science (Hancock, 2019). For example, a fundamentalist Christian student in a seventh grade biology class taking a test that asked students about the age of the earth or the origin of species could answer that the earth is 6,ooo years old and that evolution is "fake news" based on his or her religion would not lose points. I intentionally use the phrase "fake news" here given the rise of the phrase as a result of Donald Trump and, in the case of his most ardent supporters, the penchant for Evangelical Christians to assert that scientific facts somehow represent a concerted conspiracy from the

(C) KONINKLIJKE BRILL NV, LEIDEN, 2021 | DOI: 10.1163/9789004457096_003 
scientific community to downplay, diminish, or challenge their belief in the existence of God - a characteristic of the church dating back to the Inquisition and the Scientific Revolution.

Christian Reconstructionism, the philosophy and ideology behind much of the religious right's support of homeschooling is "a theocratic movement seeking to infuse our society at all levels with a biblical worldview" (Stewart, 2019, p. 103). In order to realize the goal of reshaping society to reflect specific, often narrow, Protestant-Evangelical-Conservative worldview, many use homeschooling as a method of insulating the next generation of change agents away from the influence of secular public schools. Katherine Stewart traces the growth of Christian Reconstructionism and its political connections to the Reagan administration to the Religious Roundtable's National Affairs Briefing in 1980 that propelled Regan to the status he held, and still holds, among the religious right. Reagan's rise to the presidency brought with him the influence of the religious right, including one of the most notable advocates for Christian Reconstructionism, R. J. Rushdoony. In fact,

The Christian homeschooling movement, which has played a role in indoctrinating fresh generations in a 'biblical' worldview is explicitly indebted to Rushdoony's work. The Quiverfull movement, which encourages ultraconservative Christian couples to produce as many children as possible, was in large part inspired by Rushdoony. (Stewart, 2019, pp. 103-104)

While one rationale for homeschooling is, and has always been, decidedly a religious response to what some families see as a public school system far too secular for their children, the very practice of homeschooling itself has continually been leveraged as a mechanism to affect cultural and policy changes in the broader society. In fact, the push to "supplant public schools with home schooling or religious instruction" (Phillips, 2006, p. 371) is in alignment with the theocratic tendencies of the Christian Reconstruction movement. Kieryn Darkwater opined on the close connection that Evangelical Christianity and far-right political ideology has had on both homeschooling and politics itself noting that homeschooling can, and has, been leveraged to promote far-right wing political ideologies. Further, Darkwater acknowledges that she was raised in a homeschooling family that adhered to the Evangelical movement known as "Quiverfull" that "measures a mother's spiritual resolve by the number of children she raises, each one an arrow in the quiver of God's army" (Joyce, 2006) which also carries with it tenants of racial understandings that seek to maintain the United States as a White majority populace as Joyce notes, 
Population is a preoccupation for many Quiverfull believers, who trade statistics on the falling white birthrate in European countries like Germany and France. Every ethnic conflict becomes evidence for their worldview: Muslim riots in France, Latino immigration in California, Sharia law in Canada. The motivations aren't always racist, but the subtext of "race suicide" is often there. (Joyce, 2006, para. 13)

In many ways, the preoccupation with an ideology like Quiverfull is in alignment with other right-wing White supremacist dispositions and ideologies that promote beliefs such as "White replacement theory" or "White genocide" known among alt-right circles as "The Great Replacement" (Charlton, 2019; Schwartzburg, 2019a, 2019b). And while it may be easy, or desirable to dismiss these racist dispositions as peripheral, they have, in many ways, become mainstreamed and condoned through high-profile individuals such as Trump's senior policy advisor Stephen Miller who was long believed to be a White supremacist - a fact confirmed through the release of racist emails he sent to the far-right news/blog Breitbart organization (Southern Poverty Law Center, 2019; Wilson, 2019) and of notable interest as Miller oversees the Trump administration's anti-immigrant efforts (note, however, that Trump has stated he would prefer more immigrants from Norway - a majority White nation). In her exploration of the religious nationalism practices by many on the political right and evangelical circles, Katherine Stewart points out the importance of interpreting the bible as specifically "pro-natalist" as adherents believe that

government policy should 'incentivize population growth' [Ralph Drollinger] argues, quoting Psalm 127:5, 'Blessed is the man whose quiver is full of them.' The same passage is a favorite among conservative Christians who eschew birth control in their pursuit of very large families. (Stewart, 2019, p. 50)

Drollinger, as Stewart documents, leads a weekly Bible study at the White House in which DeVos, Vice President Mike Pence, and Secretary of State Mike Pompeo, among others, are in regular attendance. This commitment to having as many children as possible and homeschooling them stands in stark opposition to perceptions of public schools that are held by many fundamentalist evangelical Christians and a desire to not only reinforce narrow religious ideology within the family but to extend that beyond and into society through politics that resembles theocracy. Specifically,

Rushdoony advocated a return to "biblical" law in America. The Bible, says Rushdoony, commands Christians to exercise absolute dominion 
over the earth and all of its inhabitants. Women are destined by God to be subordinate to men; men are destined to be ruled by a spiritual aristocracy of right-thinking, orthodox Christian clerics; and the federal government is an agent of evil. Public education, in Rushdoony's reading of the Bible, is a threat to civilization, for it "basically trains women to be men," and represents "primitivism," "chaos," and "a vast 'integration into the void." (Stewart, 2019, p. 104)

Within this mindset, public schools are to be avoided by way of homeschooling, wives/mothers should remain at home in their "wifely" roles - which facilitates the opportunity to homeschool, families that homeschool for these religious rationales should have as many children as possible so that they can then become a growing army intent on taking "back" control of government and enforcing religious-based laws and practices. And this has been going on for a while as "Evangelical conservatives started taking over their local republican parties and founding organizations like Operation Rescue, Homeschool Legal Defense Association, Family Research Council[,] and Focus on the Family, just to name a few" (Darkwater, 2017, para. 5). Darkwater goes on to argue that the HSLDA and its sister organization, Generation Joshua, was founded to

train [homeschooled children] to fight in what the Christofascists have been calling the 'Culture Wars.' It's a loose and ambiguous term that basically means anything or anyone that doesn't align with this very specific view of Christianity must not be allowed to continue. (Darkwater, 2017, para. 7)

Additionally, Darkwater suggests that to accomplish this goal,

you overturn Roe v. Wade, Griswold v. Connecticut, Brown v. Board of Education and BobJones v. The United States. Each of these decisions currently protects reproductive rights or non-discrimination based on race. As retribution, you amend the Constitution to discriminate against queers, trans people, women and people of color. Then, you make laws legislating morality. The only way to do this is to infiltrate the government; so Generation Joshua, TeenPact and other organizations exist to indoctrinate and recruit homeschooled youth who have ample free time to participate in politics. (Darkwater, 2017, para. 8)

And while some from within this religious doctrine are focused on doing what they can to shape public schools into the religious landscape they imagine such 
as DeVos's goal of using public schools to "build God's kingdom," the agenda is not limited to revamping public education. The goal is to,

Take Back The Country For Christ. This was the mantra we heard. This was our mission. This is how we were to win: Outbreed, Outvote, Outactivate. Every class, every event, every pastor or guest speaker reiterated this, choosing to risk the 501c3 status of their church to push their agenda. To take back the country for Christ, we needed to outbreed, outvote and outactivate the other side, thus saith The Lord. (Darkwater, 2017, para. 12)

Some of this requires a reinterpretation or rewriting of U.S. history as,

Self-proclaimed constitutional lawyer Michael Farris, the founder of HSLDA, and revisionist historian David Barton have spent years twisting their interpretation of the U.S. Constitution as some kind of Godbreathed document into the minds of parents and their families who will just believe what they say because they're "Good Christians." They don't necessarily practice critical thought, are dissuaded from looking at the Constitution themselves without a law degree and don't bother to read history from all angles, relying only on the whitewashed Christian versions of the Constitution and our founding. (Darkwater, 2017, para. 16)

And, seemingly, the close connection between Republican ideology and homeschooling is useful as "Republicans have a vast network of homeschoolers that HSLDA and others have given them to tap into as a source of free labor. Republicans in state governments are lax on homeschooling oversight because their Get Out The Vote base is made of homeschoolers thanks to Generation Joshua and Teenpact" further quoting Republican Senator Tom Cotton who praised the efforts of homeschooled students in their efforts to get people to vote. It is worth noting that the HSLDA maintains a page dedicated to bringing its member's attention to laws that should be supported or opposed along with a breakdown of state and federal campaigns of note (HSLDA, n.d.).

The waging of the Culture Wars at the direction of homeschooling families and the push to view the Constitution through whitewashed Christian ideology was seen as the Texas School Board revamped its science and social studies curriculum standards in 2012. The school board was largely comprised of fundamental Evangelical Christians, led by Don McLeroy, and sought to reimagine the standards to align with a narrow view of Christianity and to promote a Biblical worldview (Thurman et al., 2012). Board member Cynthia Dunbar, who later went on to become the chairperson of the Board, helped push through some of the more notable right-wing evangelical rewrites of the social studies 
and science curriculum. Of interest here is that Dunbar homeschooled all three of her children. Returning to the notion of Quiverfull, Joyce notes that adherents are interested in the,

worldly effects that a Christian embrace of Quiverfull could bring. "When at the height of the Reagan Revolution," they write, "the conservative faction in Washington was enforced [sic] with squads of new conservative congressmen, legislators often found themselves handcuffed by lack of like-minded staff. There simply weren't enough conservatives trained to serve in Washington in the lower and middle capacities." But if just 8 million American Christian couples began supplying more "arrows for the war" by having six children or more, they propose, the Christian-right ranks could rise to 550 million within a century ("assuming Christ does not return before then"). They like to ponder the spiritual victory that such numbers could bring: both houses of Congress and the majority of state governor's mansions filled by Christians; universities that embrace creationism; sinful cities reclaimed for the faithful; and the swift blows dealt to companies that offend Christian sensibilities. (Joyce, 2006, para. 32)

The belief in White homeschooling families to have as many children as possible is a notable characteristic of many American homeschooling families. Indeed, during the opening session of the Homeschooling Expo in Atlanta, the first keynote speaker (a White woman) noted that she had 7 children (Henn, 2019) - to which, the entire audience cheered and applauded loudly. Moreover, the practice of Quiverfull and homeschooling became mainstream with the popular rise of the show "19 Kids and Counting" which brought viewers into the home of the Duggar family comprised of husband, wife, and 19 children.

Aside from religious lifestyle practices related to Quiverfull and the connected political agendas that arise from within, many families that homeschool do so in an effort to situate subject curriculum to align with myopic religious doctrines. This can often take the form of a parent's desire to prevent children from being exposed to lessons on evolution, dinosaurs, and sex education to name a few. Anecdotally, I have understood the topic of avoiding evolution to be among the top curriculum rationales to homeschool in the name of religion. That is, parents who interpret their religious texts as being incompatible with the theory of evolution, or rather, evolution to be incompatible with their beliefs on the origins of Earth and humans, seek to prevent their children from exposure to the scientific theories that, on the face of it, might present the opportunity for their children to question creationism and, by extension, Christianity itself. 
Megan Fox, a fundamentalist Evangelical Christian and outspoken Trump supporter who homeschools her children, produces a myriad of videos on her YouTube channel that has approximately 4,000 subscribers. Her most popular video, viewed nearly 1.3 million times at the time of this writing, is an "audit" of the Field Museum's exhibit on evolution (Fox, 2014). In her video, Fox explores the Field's exhibitions showcasing her commitment to anti-intellectualism claiming that the "facts" that are presented are made up. Below is a transcript of the opening minutes of Fox's "audit" of the "Evolving Earth" exhibit beginning with signage on evolution:

Fox:

I don't know how to say this word so I'm just going to pretend that I know how to say it

Camera Operator: eukaryotes

Fox:

eukaryotes? Here's another interesting thing. Now they're going to tell you that this is how the evolution of a cell began.

Fox:

[reading from the signage] Eukaryotes are different from other cells [skipping the reading of "prokaryotes"] because they have a nucleus, which contains the cell's DNA, blah-blah-blah [while hand gesturing for talking].

Fox:

[skipping a few lines] At first, all eukaryotes were single-celled, and many still are today. What? If many still are today, then that would support the theory that they have never changed, that they have always been as they are today. Not that they started someplace else and then are here, they were always this, and still are today. This makes no sense ... none of this makes any sense.

Fox:

[at another wall display] How do they know this? They're talking about 470 million years ago, these are just guesses off of the top of their heads.

Fox:

[pointing to the word First] First - I love how they write these things ... this is what happened for sure, for sure, this is what happened first. Listen to how dumb this sounds! [Fox then reads from the display] "First, the ozone layer - formed when oxygen began to accumulate in Earth's 
atmosphere - provided protection from the sun's harmful radiation. Only water had provided this protection before." How do you know this? This is just a fairy tale. They're just making it up but we want the whole scientific community and everyone else to believe this.

Yet, Fox is not alone in this type of thinking that can be endemic among many who homeschool due to myopic religious and anti-intellectual beliefs. One of the most striking and disturbing that was offered during the Homeschool Expo in Atlanta was a session entitled: "The Ten Things All Future Mathematicians and Scientists Must Know (But are Rarely Taught)." From the title, it is not a far stretch to interpret the session as promoting anti-intellectualism by suggesting that those with scientific and mathematic expertise are, somehow, lacking the requisite insights and knowledge needed for their jobs as it is "rarely taught." The session description read as follows:

Mathematicians and scientists have been closely tied to many famous disasters. The Challenger explosion, the failure of the Mars Explorer, and the Kansas City Hyatt Regency walkway collapse all involved thinking errors. Our future mathematicians and scientists must know how to prevent tragedies such as these from occurring. Because science and mathematics instruction is often dominated by facts and calculation, children are rarely exposed to these important concepts. You will leave this session with many high interest stories and activities that will fascinate your children and show them the strong connections between math and science and the world we live in. (Zaccaro, 2019, emphasis added)

Clearly, there is a quite a bit to unpack here. First, there is, again, an overt foundation of anti-intellectualism and skepticism of expertise. There is a subtle hinting that experts allow their knowledge to blind them of more accurate or purer insights that, were that not the case, would not result in disasters. Secondly, the session speaker engages in some very specific cherry-picking of what were decidedly terrible disasters as one-off outliers to suggest that they are representative of a larger systemic problem within the STEM landscape. Not mentioned, of course, are the hundreds of other successful lunches and landings of the space shuttles, successful Apollo missions (many of which resulted in learning from early disasters), the successful landing and operations of other Mars rovers, and thousands upon thousands of bridges and walkways that have not collapsed. Wrought within this anti-intellectual framework and animosity towards those perceived to be intellectual elites is a mistrust and disbelief in facts and calculations. Obviously this is made abundantly clear from the 
session description above but such a disposition runs rampant within political and religious circles that interpret facts and calculations that do not align with preconceived political or religious beliefs as "fake news" while promoting ideas such as "truth isn't truth," and "alternative facts" (Kwong, 2018). The mantra that scientists and experts cannot be trusted was a foundational component of many of the conference sessions. The summary for a session entitled, "Jurassic Reality: Dinosaurs and the Most Asked Questions!" read as follows:

People of all ages are captivated by dinosaurs. Unfortunately, evolutionists use dinosaurs to indoctrinate the young and the old with an earth history that includes millions of years but has no room for the Bible. This presentation will show the power of a person's starting assumptions (or "worldview") when interpreting past events, and will define the different types of sciences used in investigating the world around us, with a thorough exploration of these enigmatic lizards. Let's take dinosaurs to the Bible and see what God's word has to say about them! (Sarfati, 2019)

A notable right-wing, anti-science Christian persona in this landscape is Ken Ham who famously debated Bill Nye on the topic of evolution and is the director of the Ark Encounter (a built-to-biblical-scale replica of Noah's ark). In addition to his work related to the Ark Encounter, Ham produces or appears across a myriad of Christian-based educational curriculum for homeschooling families. One such program from Ham's "Answers in Genesis" organization is a DVD titled "Dinosaurs, Genesis \& the Gospel" where Ham lectures on dinosaurs while Buddy Davis sings original bible-based songs on the same topics (Ham \& Davis, 2004). Below is a transcript of the sample portion of Ham's lecturer which was recorded in front of an auditorium of parents and their children:

Well, boys and girls, put your hand up if you've heard the word evolution. Oh boy, just about everyone put their hand up. Put your hands down. Put your hand up if you've heard that dinosaurs lived millions of years ago. Dear, oh dear, hands down. Put your hand up if you've heard that people came from ape-like creatures or something like that. You know, I think just about everyone in the world has heard those things. I want to tell you right from the start here this morning that neither Buddy nor myself, we don't believe in evolution. Evolution is the idea that some people have to explain life and our God. You know, when you came in here this morning did you look at this building and say, 'wow, it got here by an explosion in a brick factory? You don't think that? No, you know somebody designed this building and I certainly don't believe 
that life came about by chance random processes millions of years ago in some soup in the sea, life was formed and then one kind of animal changes into another ape-like creatures and then into people until finally here we are in Pennsylvania. I don't believe that all, do you? ... I don't believe that dinosaurs lived millions of years ago. And I certainly don't believe, and neither does Buddy, that you came from ape-like creatures. I mean, in fact, did your grandfather look like that? [shows a caricature composite photo mixing a human face with an ape's face - to which the children laugh], I don't think so. Does your grandmother look like that? [shows the same picture now with makeup - to which the children laugh louder]. (Ham \& Davis, 2004)

Ham goes on to reinforce that he believes that the Bible is the "history book of the universe" - a point he makes the children parrot. The picture of the workbook created by Ham and Davis that accompanies the video is a smiling tyrannosaurus rex smiling while holding a glowing Bible.

While many homeschooling families purchase curriculum designed specifically for homeschooling - often with the additional feature of centering religious instruction or religion-based alternative perspectives on settled science - there are a plethora of online and free curriculum resources available. Still, many of these resources center religion. For example, the "Easy Peasy All-In-One Homeschool" site provides content and lesson planning for homeschooling families from pre-K through high school (Easy Peasy All-In-One Homeschool, n.d.-b). Notably, the first lessons for pre-K students center on using content from the McGuffey's Readers which were widely used in common schools between the mid 1800 s to the mid 19oos to reinforce a religious and Bible-based orientation to reading. The site's owner is clear that the purpose of homeschooling and the curriculum provided is to not only advance a Christian perspective but also to provide insights into how to argue against mainstream scientific insights that are interpreted as not in alignment with a particular and specific interpretation of the Bible that is not shared among all Christians. The site notes that,

This is a Christian curriculum. Most things are not overtly Christian, but I do point to the Bible from time to time in literature, science, history, etc. and seek to promote a biblical worldview. I also believe in a literal six-day creation. I do choose to use materials that talk about millions of years because it is what's available, and it's useful for our children to know what's taught out there so they can be intelligent in a response to it. I do address it to varying degrees when it comes up. (Easy Peasy All-In-One Homeschool, n.d.-a) 
However, while some attention is given to scientific theory surrounding the age of the earth - if only to learn how to "respond" to it, the curriculum designer specifically avoids exposing students to religions other than Christianity. For example,

I also don't study false religion [in the homeschooling curriculum]. My children know the basics about it, but you won't find me teaching them about the gods of Ancient Egypt for example. They will know they had a false religion and worshiped other gods, but we don't need to learn all of their names and what they looked like. It also makes me careful around things like Native Americans and their spirit guides, etc. Not all literature the children will read is pure in every way. But, that's a way to talk about the world and choices and consequences and how we should react in certain circumstances ...

Ensuring that children are not exposed to competing understandings of the world - religious or otherwise - should raise significant questions about the quality of education and its ability to prepare children to become adults in a multicultural world. Occasionally, a local or national news story brings attention to Christian parents who are irate at the suggestion that their student in public school be exposed to any religion other than Protestant Christianity. This takes on the form of overt discussions and learning related to world religions but also surrounding innocuous practices such as yoga because it is understood as being explicitly anti-Christian and schools that offer yoga amounts "to a tacit endorsement of a non-Christian belief system" (Rojas, 2020). Tucker Carlson, the host of a wildly popular primetime show on Fox News, held a segment with two mothers who were protesting a New Jersey public school for their teaching of the five pillars of Islam. According to them, this amounted to a liberal attempt to brainwash students into becoming Muslim - a disposition that generally aligned with rhetoric on Fox News during the Obama administration given the network's promotion of the conspiracy theories that Obama was a secret Muslim attempting to bring Sharia Law into the United States by indoctrinating students. Conspiracy theories aside, the parents from New Jersey insisted, quite vehemently, that the public school was pushing Islam onto students and had never covered Christianity. Despite such claims, the state standard for the social studies curriculum in the 6th grade which is nearly identical to all social studies standards for middle and high school social studies and history. The standard reads,

Compare and contrast the tenets of various world religions that developed in or around this time period (i.e., Buddhism, Christianity, Confu- 
cianism, Hinduism, Islam, Judaism, Sikhism, and Taoism), their patterns of expansion, and their responses to the current challenges of globalization. (New Jersey Department of Education, 2014, p. 37)

Contrary to the self-selected and self-isolated curriculum that refuses to explore the tenets of world religions (even those that are connected to Christianity as Abrahamitic faiths - e.g., Islam and Judaism), is the public school curriculum that promotes a broad range of skills necessary for citizenship. In fact, according to the New Jersey Department of Education, the mission of its social studies curriculum is to provide "learners with the knowledge, skills, and perspectives needed to become active, informed citizens and contributing members of local, state, national, and global communities in the digital age" (Plein, n.d.). Moreover, the curriculum seeks to foster a population that,

- Is civic minded, globally aware, and socially responsible.

- Exemplifies fundamental values of American citizenship through active participation in local and global communities.

- Makes informed decisions about local, state, national, and global events based on inquiry and analysis.

- Considers multiple perspectives, values diversity, and promotes cultural understanding.

- Recognizes the implications of an interconnected global economy.

- Appreciates the global dynamics between people, places, and resources.

- Utilizes emerging technologies to communicate and collaborate on career and personal matters with citizens of other world regions. (Plein, n.d.)

Compare this disposition, again, to the possibility that homeschooling curriculum can, and often does, cherry-picking topics that suit a specific world-view or sterilized version of history. The Easy Peasy online homeschooling curriculum avoids some videos surrounding WwII "because I didn't want those images in front of their eyes, even if they are truth" (Easy Peasy All-In-One Homeschool, n.d.-a). But this selectivity is not limited to historical events as it exists even surrounding the Biblical orientation of the curriculum by cherry-picking the nicer portions of the Bible in an effort to avoid the more difficult sections or context of the text,

One final note about the Bible curriculum: I don't have them read everything. For example, when I put up Sodom and Gomorrah, they read that it was destroyed because of their great sin, but they don't read the part about what the people there died. And I stopped before Lot's daughters 
decide they need his help to continue the family line. You can't avoid it all; I mean, Jacob has twelve sons, but it's not hard to skip over what happened to their sister Dinah. (Easy Peasy All-In-One Homeschool, n.d.-a)

Another popular Christian curriculum available to homeschooling parents is produced by "My Father's World." In addition to the curriculum website, the organization mails periodic book catalogues much in the way that academic presses do announcing new textbooks. The approach offered by My Father's World “combines the best of Charlotte Mason's ideas, classical education, and unit studies with a biblical worldview and global focus. By keeping God's Word central, we partner with you to provide life-transforming, academic excellence with a Christian worldview" (My Father's World, n.d.-b). The provided high school "Ancient History and Literature" material is a "verse-by-verse reading of the entire Old Testament [that] encourages challenging, practical, daily application. Worldviews of ancient societies and their literature are studied and compared to a Biblical worldview" (My Father's World, n.d.-a).

In sum, the religious rationale to homeschool may be one of the most closely-held rationales given the power that religion plays in the lives of so many people (homeschooling or not). On the surface, public schools are seen as a direct threat to the ability to freely practice a chosen religion or a threat to the social morality that is intertwined within the religion. The goal for some using the religious rationale is to have their children avoid public schools while preparing them for a life of political and policy work that will reimagine public schools along myopic Protestant Evangelical lines as schools are seen as a mission field.

\section{References}

Associated Press. (2008). Education officialstands by her Obama terror claim. Retrieved November 19, 2019, from https://www.chron.com/news/houston-texas/article/ Education-official-stands-by-her-Obama-terror-1772463.php\#item-85307-tbla-2 Charlton, L. (2019). What is the great replacement? https://www.nytimes.com/2019/ o8/o6/us/politics/grand-replacement-explainer.html

Darkwater, K. (2017). I was trained for the culture wars in home school, awaiting someone like Mike Pence as a messiah. Retrieved October 1, 2019, from https://www.autostraddle.com/i-was-trained-for-the-culture-wars-in-homeschool-awaiting-someone-like-mike-pence-as-a-messiah-367057/?fbclid= IwAR3kıdiy58NGbHyljo8ss4PVYnbSY5DAZotd484iGvbRgdofUdDcOyeXgrM 
Dunbar, C. (2008). One nation under god: How the left is trying to erase what made us great. HigherLife Publishing.

Easy Peasy All-In-One Homeschool. (n.d.-a). About/donate. Retrieved February 25, 2020, from https://allinonehomeschool.com/about/

Easy Peasy All-In-One Homeschool. (n.d.-b). Mcguffey primer. Retrieved February 25, 2020, from https://allinonehomeschool.com/days-172-222-mcguffey-reader/

Fox, M. (2014). Megan Fox audits the field museum's "evolving earth" exhibit. Retrieved October 1, 2019, from https://www.youtube.com/watch?v=32mxZxv3dYM

Ham, K., \& Davis, B. (2004). Dinosaurs, genesis \& the gospel, dvd. Retrieved March 1, 2020, from https://www.christianbook.com/dinosaurs-genesis-the-gospel/ pd/oo154X?event=Homeschool\%7C10o6429\#customer_reviews

Hancock, L. (2019). Ohio lawmakers clear bill critics say could expand religion in public schools. Retrieved November 19, 2019, from https://www.cleveland.com/open/ 2019/11/ohio-lawmakers-clear-bill-allowing-students-to-turn-in-inaccurate-workin-name-of-religion-second-anti-science-bill-in-a-week.html

Henn, J. (2019). Take the mystery out of homeschooling. Paper presented at the Southeast Homeschool Expo, Atlanga, GA.

HSLDA. (n.d.). Current campaigns. Retrieved March 26, 2020, from https://hslda.org/ content/legislation/?vvsrc=/Campaigns

Joyce, K. (2006). 'Arrows for the war'. Retrieved October 1, 2019, from https://www.thenation.com/article/arrows-war/

Kwong, J. (2018). 'Truth isn't truth': Here are all the ways trump's administration has claimed facts are no longer real. Retrieved July 29, 2019, from https://www.newsweek.com/truth-isnt-truth-here-are-all-ways-trumpsadministration-has-claimed-facts-1081618

My Father's World. (n.d.-a). 9th-12th grade: Declare. Retrieved February 27, 2020, from https://www.mfwbooks.com/cat/14/

My Father's World. (n.d.-b). Curriculum for homeschool \& christian schools. Retrieved February 27, 2020, from https://www.mfwbooks.com/aapproach

New Jersey Department of Education. (2014). New Jersey student learning standards for social studies. Retrieved February 25, 2020, from https://www.nj.gov/education/ cccs/2014/ss/standards.pdf

Phillips, K. (2006). American theocracy: The peril and politics of radical religion, oil, and borrowed money in the 21st century. Penguin Books.

Plein, B. (n.d.). New Jersey student learning standards: Social studies. Retrieved February 25, 2020, from https://www.nj.gov/education/aps/cccs/ss/

Rizga, K. (2017). Betsy DeVos wants to use America's schools to build "god's kingdom." Retrieved February 12, 2018, from https://www.motherjones.com/politics/2017/o1/ betsy-devos-christian-schools-vouchers-charter-education-secretary/ 
Rojas, R. (2020). In a plan to bring yoga to Alabama schools, stretching is allowed. 'Namaste' isn't. Retrieved March 10, 2020, from https:/www.nytimes.com/2020/o3/og/us/ alabama-yoga-schools.html

Ryan, E. (2019). There's a push for classes on the bible in public schools. And there's also a pushback. Retrieved May 1, 2020, from https://www.cnn.com/2019/05/06/politics/ bible-literacy-classes-legislation/index.html

Sarfati, J. (2019). Jurassic reality: Dinosaurs and the most asked questions! Paper presented at the Southeast Homeschool Expo, Atlanta, GA.

Schwartzburg, R. (2019a). No, there isn't a White genocide. Retrieved May 1, 2020, from https://www.jacobinmag.com/2019/og/white-genocide-great-replacement-theory

Schwartzburg, R. (2019b). The 'White replacement theory' motivates alt-right killers the world over. Retrieved May 1, 2020, from https://www.theguardian.com/commentisfree/2019/aug/o5/great-replacement-theory-alt-right-killers-el-paso

Sheasley, C., \& Jonsson, P. (2019). More public schools are embracing the bible. Is it literature, or religion? Retrieved May 1, 2020, from https://www.csmonitor.com/ USA/Education/2019/og18/More-public-schools-are-embracing-the-Bible.-Is-itliterature-or-religion

Southern Poverty Law Center. (2019). Stephen Miller: The Breitbart emails. Retrieved November 19, 2019, from https://www.splcenter.org/stephen-miller-breitbart-emails

Stewart, K. (2019). The power worshippers: Inside the dangerous rise of religious nationalism. Bloomsbury Publishing.

Thurman, S. (Writer and Producer), Silver, P., \& Wood, O. (Producers). (2012). The revisionaries [Film]. PBs.

Wermund, B. (2016). Trump's education pick says reform can 'advance god's kingdom'. Retrieved January 4, 2017, from http://www.politico.com/story/2016/12/betsydevos-education-trump-religion-232150

Wilson, J. (2019). Leaked emails reveal Trump aide Stephen Miller's White nationalist views. Retrieved May 1, 2020, from https://www.theguardian.com/us-news/2019/ nov/14/stephen-miller-leaked-emails-white-nationalism-trump

Zaccaro, E. (2019). The ten things all future mathematicians and scientists must know (but are rarely taught). Paper presented at the Southeast Homeschool Expo, Atlanta, GA. 